\title{
Interview with scholar, translator and lexicographer Donald Rayfield
}

Professor Donald RAyfield in CONVERSATION WITH SLOVO'S EXECUTIVE Editor BRYAN KARETNYK

Queen Mary University of London (Department of Russian) and UCL School of Slavonic and East European Studies

Donald Rayfield is Emeritus Professor of Russian and Georgian at Queen Mary, University of London. He has been at the forefront of Georgian studies for many years and has published widely on Georgia, authoring several major studies on its literature and history, and translating works by Galaktion Tabidze, Otar Chiladze, Akaki Tsereteli and, most recently, Mikheil Javakhishvili. Slovo meets him to find out about the past, present and (speculative) future of this rich but much underrepresented literature in the Anglophone world.

\section{BRYAN KARETNYK: How did you come to Georgia and Georgian literature?}

DONALD RAYFIELD: By accident... Early in my career I was most interested in twentieth-century Russian poets, and in particular Mandelshtam, Pasternak and Zabolotsky, who all had close contacts with Georgians and Georgian poetry, for whom Georgia was a refuge at times of oppression. I meant to study their correspondence in the Literary Museum in Tbilisi. When I got there in 1973, I was constantly frustrated - the key was lost, the director was out, and so on - until one of the girls working there took pity on me and told me that, as a British spy, I was not going to be allowed to see anything. I switched to the university Georgian language department, where there was less KGB, and was lucky enough to become like Dr Johnson's woman who preached in church, or a dog that walked on its hind legs - a Briton who learnt to speak Georgian, not particularly well, but miraculous none the same. That led to involvement with Georgia's dissidents (the future president [Zviad] Gamsakhurdia), poetry and, after thirty years' complaining about the absence of a decent dictionary, to lexicography.

BK: Yes, on that point, I'd imagine compiling any dictionary, let alone a bilingual one, to be an uncommonly daunting task. How exactly did you come to undertake it? What was it like? 
DR: First of all, I knew the people in Georgia best able to help: Shukia Apridonidze who had taught me Georgian thirty-five years before and had become the presenter of a TV programme on writing correct Georgian; the linguist Ariane Chanturia, the son of a Scottish mother and Georgian father, then in his eighties, but still perfectly bilingual; a computer expert, Levan Chkhaidze, who had been employed by the Red Army to calculate the casualties of World War III and whose skills were ideal for calculating all the occurrences of Georgian words in the press that were not to be found in the dictionaries; Laurence Broers, a brilliant student who could charm his way into any milieu, from warlords and drug-dealers to bishops and peasants, in search of colloquial jargons; Rusiko Amerijibi-Mullen, a woman who had been married to a Texan long enough to overcome the taboo Georgian women observe about not revealing the language they use when no men are present. Secondly, the Arts Funding councils in 2001 were for the first time biased in favour of lexicography. Thirdly, Leverhulme were willing to award me three years' freedom from other duties to get the project underway. The work is unimaginably extensive, but quite therapeutic, like basket-weaving: I understood why the Oxford English Dictionary was compiled largely with the help of the inhabitants of Broadmoor.

BK: Was your longstanding background in Russian in any way key to accessing Georgian language and literature?

DR: In a way, yes, because the Georgian intelligentsia in Tsarist and Soviet times was interconnected, even intermarried, with Russia, and in Tbilisi then (if not now) educated Georgians were bilingual in Russian. But it could be a barrier: if you spoke bad Georgian, you were answered in serviceable Russian, whereas learners who knew no Russian made faster progress. As for literature, Russian has only slightly influenced Georgian, which is too rooted in its own medieval writing, its own poetics and in its own folklore to be very susceptible to Russian novels, lyrics or drama.

BK: Fascinating. In that case, where does Georgia's literary heritage situate itself? What are its historical influences? Can we speak of a 'national character' in Georgian literature? 
DR: Like all nations whose past (in Georgia's case, twelfth century) was more glorious than its present, history is the main concern of Georgian writers, and they (rightly) see their old predicaments constantly repeated - choosing between a western or an eastern tyranny, defending Christian heritage from Islam, maintaining courtly values against commercial ones. The national character is expressed by recreating heroes or lyrical personas in the image of suicidal folk-heroes, Christian martyrs, or desperate defenders of national independence. There still is an Oriental, specifically Persian influence in depictions of hyperbolic love (all those Persian prototypes of Romeos and Juliets: Leila and Majnun, Vis and Ramin) and in a fondness for virtuoso games with rhyme and metre. In the last two decades, English and American influences on the novel and on drama have become noticeable, but the national character remains constant.

BK: So did outside influences become more prevalent during the twentieth century? I'm thinking specifically in terms of the effects of Soviet era on the literature. Did it reorient itself in any significant way?

DR: Soviet influence was lighter than you'd expect, largely because of the state planning involved: Georgians were assigned the role of historical novelists, as they had so much history to digest; literature of socialist construction was written, but all of it is forgettable. Stalin's support of the historical novelist Konstantine Gamsakhurdia allowed some extraordinarily un-Soviet prose to be written. Georgia benefited less from the post-Stalin thaws, and it is not until the late 1960s that the Georgian leadership became nationalist enough to allow real independent novels. The Soviet pattern of 'taking in each other's washing', whereby national novelists who behaved properly were enriched by having translations of their works for a vast Russian readership, benefited Georgians: Russians then appreciated the greater freedom of thinking conceded to Georgians, and the Russian censor never bothered to read a translated work, assuming that the Georgian censor had done his job properly.

BK: How trusting of him... Did any particularly subversive material manage to fall through the cracks? 
DR: It did, because Georgian leaders, even if nominally Communist, allowed themselves the pleasure of dropping spanners in the Soviet works: thus Lavrenti Beria in the 1930s befriended the only true Fascist in Georgia, the novelist Gamsakhurdia [Konstantine Gamsakhurdia, father of former president Zviad Gamsakhurdia - Slovo] and let him publish a novel which caricatured Beria himself as an incestuous rapist. Or the Georgian censor would be so stupid as to fail to see the implications of, say, Otar Chiladze's novel about the conquest of Colchis by Jason and the Argonauts as an allegory of the conquest of Transcaucasia by Russians and Soviets; once passed by the Georgian censor, the Russian censor would pass a work without even bothering to read it. Cinema, in which Georgians excelled and which Party bosses, too tired to read, loved, was particularly free: hence the Christian symbolism of Invocation and the startling political radicalism of Repentance (even though it had to be re-shot because Shevardnadze had the boy-actor shot for attempting a hijack).

BK: Turning our attention now to the adventures of Georgian literature further abroad... Does the translation of Georgian literature into English really begin with Marjory Wardrop, as is commonly assumed? Do we in fact know whether Wardrop, as Vladimir Nabokov wondered in his review of her translation ['Crystal and Ruby', New Republic, 25 November 1940], worked - at least in partfrom Russian?

DR: There were a few samples of Georgian before Marjory Wardrop, largely of ecclesiastical history. The Wardrops were in fact geniuses: although they knew Russian, they worked exclusively from Georgian-the English translation of Rustaveli preceded the first full Russian version. Sadly, very little work followed the Wardrops', except for scholarly versions of the Georgian chronicles. In Moscow a lot of modern Georgian literature was published in English, but these were translations from a Russian version, done by British communists who had forgotten their English.

BK: In your experience, does Georgian lend itself well to being rendered into English? 
DR: No worse than any other major literary language in the Christian tradition: we are not dealing with, say, Japanese or Amerindian languages and cultures, where so many concepts as well as word relationships are alien.

BK: In addition to your numerous critically acclaimed works on Russian history, literature and culture, you have also written a history of Georgian literature, edited a Georgian-English bilingual dictionary and translated several volumes of Georgian poetry and prose. What are the main challenges in translating from Georgian? In your experience, are they any different from translating, say, Russian literature?

DR: The main challenges in my view are the lack of resources: really good dictionaries for the use of non-native speakers; the limitations of Google.ge; the paucity of predecessors. The language is, of course, exceptionally rich-it has an unbroken literary tradition of 1,600 years, and many varied dialects and jargons are still alive, especially in the work of novelists. Older Georgian writers often like the obscurity of punning rhymes, and many works exist in manuscripts that have been copied by careless scribes, so that major texts puzzle Georgian critics themselves. But the language itself, with its syntax, like ours, modelled on New Testament Greek, is not insurmountable.

BK: How do you view the state of Georgian literature today, both at home and abroad? Have foreign publishers become more supportive, given recent initiatives such as Dalkey Archive's Georgian Literature Series?

DR: Saakashvili's main achievement was to bring about enough prosperity to make reading, writing and publishing all commercially viable again, after near-death of culture in the 1990s. The theatre and cinema have also recovered. Abroad, Georgian has had less success: Georgian poets are invited to festivals, largely as performers (as are their dancers, singers and film actors). Their drama encounters resistance, although some of the best satire in the world is now being performed in Tbilisi. It is very hard to get publications of Georgian fiction reviewed, let alone marketed. I have personal experience of failure to interest critics and readers with two novels by Otar Chiladze that I still regard as important and interesting. Dalkey Archive has done a lot, but I fear sales have yet to take off. The Georgian Ministry of Culture, like 
many East European ministries, runs a subsidy programme which covers the cost of translation, but the takers are few.

BK: I suppose, then, the problem is twofold: on the one hand, the reticence of major publishers to take on books that might be seen as risky or unconventional and, on the other, a lack of advocates for the literature. How do you envisage the future of Georgian literature in the English-speaking world?

DR: One problem is the lack of translators: Georgians themselves dare to make their own translations, but these, however qualified the translator, will never be of acceptable quality, even with pro-active editors; there is an urgent need for more translators, and the best hope for the future will be the bilingual products of mixed marriages.

BK: Thank you so much for this fascinating insight into the literature and your own history with it over the years. To conclude, perhaps we might ask you: what, for you, are the pearls of Georgian literature, translated or untranslated?

DR: The pearls are largely in verse: two eighteenth-century poets, Davit Guramishvili and Besik Gabashvili are known only in Russian translation. Vazha Pshavela, writing in the 1880 s to 1910 s, is one of the most original poets on earth, especially in his longer poems which seamlessly merge folk heroic poetry with Euripides and Shakespeare. The poets of the 1920 and 1930s-Galaktion and Titsian Tabidze in particular-are little known in English (again, under the Soviets they were competently translated into Russian). As for prose, Georgians tend to suffer from the lack of editors and from the old Russian habit of paying authors by the line: most good twentieth-century novels would benefit from cuts. Kvachi Kvachantiradze, which I translated for Dalkey Archive, seems to me the best of all Georgian novels a rogue novel combining Bel Ami and Till Eugenspiegel. There is much from the preRussian era: the seventeenth-century Rusudaniani, with its tragic frame story of a forlorn queen, consoled by a series of stories; the early-nineteenth-century Tristam Shandy-like Alms-Gathering by Crown Prince Ioane, which is a mixture of encyclopaedia and free-association novel-writing. One day, perhaps, a poet translator will find a way of rendering The Knight in the Panther's Skin. Wardrop's 
prose version is fine, but the constant play of rhyme and assonance that a verse version would give is missing.

London-Otford, March 2015

\section{Biography}

Born in 1942 and educated at Dulwich College and the University of Cambridge, Donald Rayfield first visited Georgia in 1973. He has translated a number of Russian and Georgian poets, playwrights and prose writers, his most recent translation being Mikheil Javakhisvili's classic novel Kvachi Kvachantiradze. He has also authored several major works on Georgia, including Edge of Empires and The Literature of Georgia: A History, and edited A Comprehensive Georgian-English Dictionary. In addition to his work in Georgian studies, he has written widely in the field of comparative literature and is the author of a biography of Anton Chekhov and the study Stalin and His Hangmen, both of which have been translated into other languages, including Russian. Rayfield now continues his research, living in Kent, where he cultivates a passion for horticulture, especially exotic trees.

This work is licensed under the Creative Commons Attribution-Non-commercial-Share-alike 2.0 UK: England \& Wales License. This license allows for redistribution and alteration, commercial and non-commercial, as long as credit is given to the author. To view a full copy of this license, visit: http://creativecommons.org/licenses/ or send a letter to Creative Commons, 444 Castro Street, Suite 900, Mountain View. 